\title{
Irineu Strenger assume a titularidade de Direito Internacional Privado.
}

Irineu Strenger, novo titular de Direito Internacional Privado, nasceu nesta cidade a 20 de outubro de 1923 . É filho de Bernardo Strenger e de D. Rosa Kaufman Strenger.

Fez o curso fundamental no Liceu Rio Branco, no período de 1934 a 1939 , e sua complementação no Colégio Carlos Gomes, desta capital. De 1942 a 1945 freqüentou a Secção de Filosofia, Ciências e Letras da Universidade de São Paulo, onde, prestando concurso de habilitação, bacharelou-se e licenciou-se em filosofia.

Em 1953, ingressou na Faculdade de Direito da USP, colando grau em Ciências Jurídicas e Sociais em 1958. Graduado por duas Faculdades, continua seus estudos freqüentando vários cursos de extensão universitária, sobre temas de grande importância para sua formação filosófico-. -jurídica, não somente na Faculdade de Filosofia da USP, mas, também, na Escola Superior de Guerra em São Paulo, na Escola de Sociologia e Política de São Paulo, no Instituto Brasileiro de Filosofia e no Forum Roberto Simonsen.

Inicia suas experiências docentes como professor de Psicologia no Instituto Brasileiro de Filosofia, depois de matemática e filosofia em vários colégios da Capital. Reconhecendo-lhe os méritos didáticos e de invulgar cultura filosófica, o professor Miguel Reale convida-o para ministrar, como instrutor voluntário, as aulas de Filosofia do Direito no curso de bacharelado desta Faculdade. Inicia, pois, em 1962, sua vertiginosa carreira de professor universitário. Em 1964, submete-se a concurso para a livre docência de Filosofia do Direito, defendendo a tese: Dogmá- 
tica Jurídica (Contribuição do Conselheiro Ribas à Dogmática do Direito Civil Brasileiro), obtendo média 8,55. Após a livre docência de Filosofia, é nomeado, em 2 de abril de 1965, professor assistente de Filosofia do Direito; em abril do mesmo ano, passa a reger a cadeira de Direito Internacional Privado, até 1967, quando se submete a concurso para a livre docência da mesma matéria; defende com distinção, média 9,4, a tese: Da Autonomia da Vontade em DIP. Substitui, então, o titular da cátedra, professor Luís Antônio da Gama e Silva, inclusive no curso de especialização, que posteriormente passou a denominar-se Curso de Pós-Graduação.

$\mathrm{Na}$ regência da cátedra de Direito Internacional Privado, Sua Excelência inova e dinamiza os métodos de ensino da matéria, exigindo e estimulando a participação dos alunos em trabalhos de pesquisa e debates, para a solução de problemas internacionais, atuais e judiciosamente escolhido.

Dedica, também, atenção especial aos clássicos dos quais se fizeram várias traduções; convida especialistas da matéria para conferências; analisa, com os alunos, casos concretos e as respectivas decisões, como por exemplo o caso Tobago e outros; entusiasmam-se, de tal forma, alunos e auxiliares de ensino que preparam para publicação um volume de 400 páginas datilografadas, sobre os assuntos pesquisados, isto é, sobre: A Possibilidade do Investimento Estrangeiro no Mercado de Capitais, Importação e Exportação.

A par de sua atividade docente, o professor Irineu Strenger exerce, também, cargos administrativos de alta responsabilidade, ou seja, o de Coordenador de Saúde e Assistência Social da Universidade de São Paulo, tendo sido também, Diretor da Faculdade de Comunicações da Fundação Armando Álvares Penteado. A atividade intensa do professor Irineu Strenger desdobra-se em vários sentidos, e além do ensino, da advocacia e dos cargos adminis- 


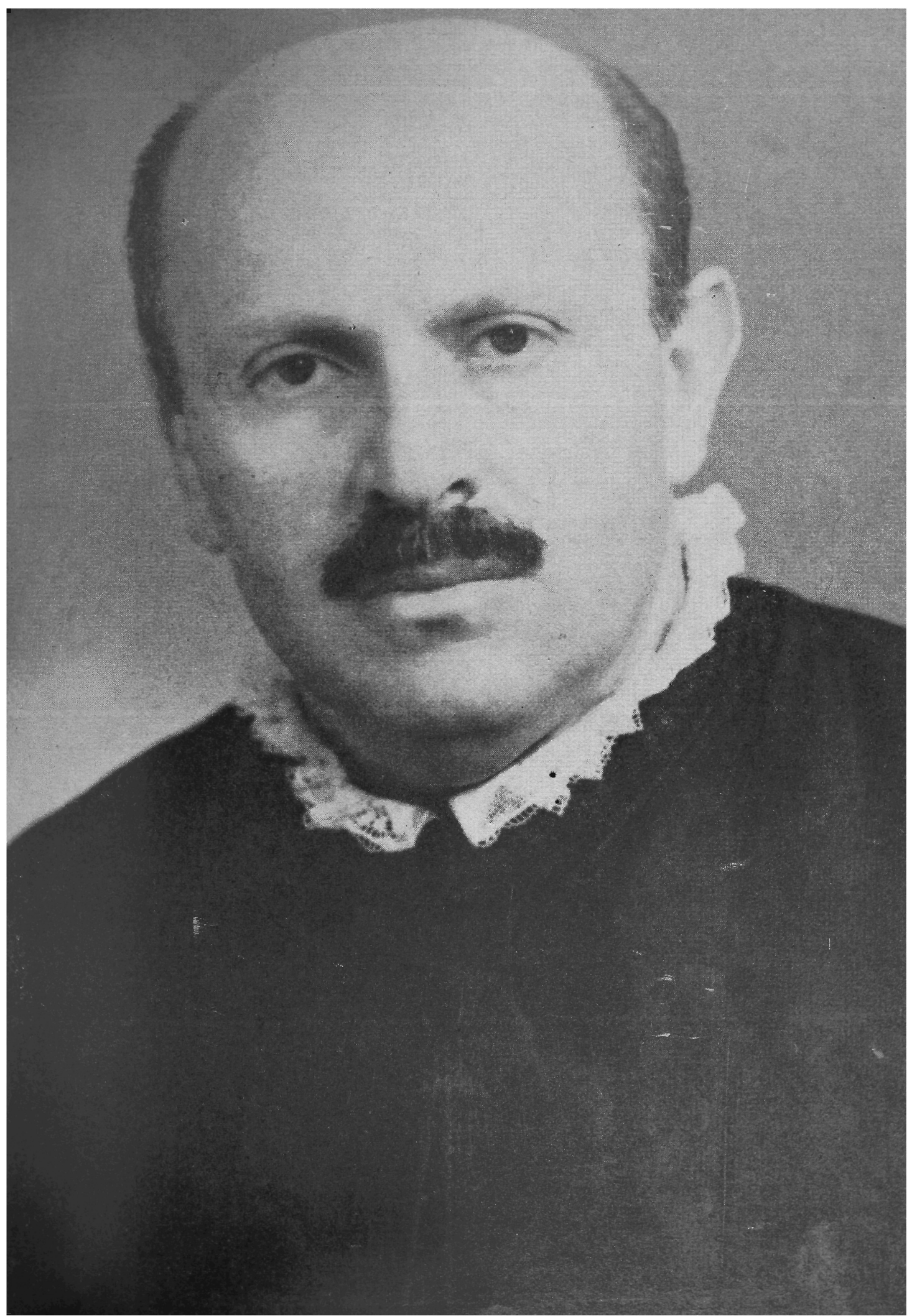


Professor Dr. Irineu Stranger, titular de Direito Internacional Privado. 
trativos, Sua Excelência projeta as radiações de sua inteligência privilegiada às várias associações das quais participa, como membro titular ou suplente; aos congressos internacionais, como membro ativo, representando o Brasil, e às bancas examinadoras das quais fez parte. É, pois, membro titular da Comissão da Editora da USP e da Revista dos Tribunais. Membro titular do Conselho Estadual de Saúde, como representante da USP. Do Instituto Brasileiro de Filosofia, da Comissão Internacional de Juristas (secção de São Paulo), da International Law Association, da Sociedade Brasileira de Direito Internacional. É membro suplente do Conselho Estadual de Promoções Sociais, do Conselho Universitário da USP, do Conselho Estadual de Cultura do qual foi presidente, da Comissão de Ciências Humanas e membro titular efetivo do Instituto dos Advogados de São Paulo, da Associação dos Advogados de São Paulo, da Sociedade Brasileira de Direito Criminal e do Centro de Cultura Jurídica Alcântara Machado.

Participou, como membro ativo, de inúmeros Congressos Internacionais de Filosofia, de Direito Internacional e de Direito Comparado. De Filosofia em São Paulo (1954), em Washington (1957), em Buenos Aires (1959), no México (1963), em Viena (1968), em Bruxelas (1971). De Direito Internacional e Comparado, promovido pela International Law Association, na cidade de Haia (1970), e no de Direito Comparado realizado em Pescara, Itália, em 1969. Integrou várias bancas examinadoras, nesta Faculdade e na Faculdade de Filosofia do Rio Grande do Sul, para concursos à livre-docência, doutoramento e julgamentos de teses do concurso de especialização.

A convite do governo alemão, visita e mantém contacto com as universidades daquele país em 1970. Valiosíssima é também a contribuição bibliográfica de Irineu Strenger à Filosofia do Direito e ao DIP, tendo publicado os seguintes trabalhos: 


\section{Bibliografia.}

Sociologia das gerações, 1951, Editora Martins em colaboração.

A matéria como categoria filosófica, separata da Revista Brasileira de Filosofia, 1958.

Influências de Husserl no. pensamente jusfilosófico brasileiro, 1959.

O problema da liberdade na órbita do direito, separata da Revista Brasileira de Filosofia, 1959.

$O$ ensino da filosofia no curso secundário, Revista Brasileira de Filosofia, v. V, f. IV, p. 649.

Da liberdade segundo Espinosa, Revista Brasileira de Filosofia, v. VII, fasc. I, p. 538 .

Marxismo e positivismo, Revista Brasileira de Filosofia, v. VII, f. I, p. 60 .

Problemática Humana da técnica, Comunicação ao XIII. Congresso Internacional de Filosofia, realizado no México, 1963.

Contribuição de Miguel Reale à Filosofia do Direito e do Estado, in Miguel Reale Filósofo e jurista.

Dimensão filosófica da liberdade. Revista Brasileira de Filosofia, v. 44, p. 445 .

Rousseau e a escola positivista, edição da Universidade do Ceará, 1962.

Controvérsias em torno do pensamento rousseauniano, separata da Revista Brasileira de Filosofia.

Oposição à posse e prescrição aquisitiva, embargos sustentados perante - Supremo Tribunal Federal, editora Cúpulo, 1963.

Tradução do livro Filosofos brasileños de Guilhermo Francovich.

Recensão do livro $E l$ problema de lo finito y lo infinito, de S. Meliujin Revista Brasileira de Filosofia, v. 43, p. 415.

Da Dogmática jurídica, edição da imprensa oficial do Estado 1964 (tese com que conquistou a livre-docência de Filosofia do Direito na Faculdade de Direito da Universidade de São Paulo).

Da autonomia da vontade em Direito Internacional Privado, 1967 (tese com que conquistou a livre-docência de Direito Internacional Privado, na Faculdade de Direito da Universidade de São Paulo).

Teoria Geral do Direito Internacional Privado, José Bushatsky, 1972 (no prelo).

Problemas práticos de Direito Internacional Privado editora José Bushatsky, 1974.

Fenomenologia e criticisma ontognoseológico, Revista da Faculdade de Direito, 1966. 
Hegel e Husserl: duas fenomenologias?, separata da Revista Brasileira de Filosofia, 1970.

Dialética da experiência jurídica, separata da Revista Brasileira de Filosofia, 1970.

A noção espaço e tempo na filosofia pós-hegeliana, separata da Revista Brasileira de Filosofia, 1960.

$A$ originalidade de "cogito" de Descartes, edição particular, 1960.

Da liberdade segundo Espinosa, separata da Revista Brasileira de Filosofia, 1961.

Interpretação gestáltica da estética, in Anais de Congresso Internacional de Filosofia, de 1954.

Filosofia e maquinismo edição do Forum Roberto Simonsen, 1959.

Empresas Multinacionais, editora José Bushatsky (no prelo).

Reparração do dano em direito Internacional Privado, editora Revista dos Tribunais, 1972.

Regime Jurídico de relação empregatícia em direito internacional Privado, publicado também em Alemão, parecer, 1974.

\section{A conquista da Titularidade de DIP e a cerimônia de posse.}

Em outubro de 1972, com o cabedal de títulos docentes e administrativos e a rica bibliografia apresentados, Sua Excelência submete-se a concurso para a titularidade de Direito Internacional Privado. Defende a tese Regime Juridico da Reparação do Dano em Direito Internacional Privado e é aprovado com distinção, por unanimidade, obtendo a média 9,45 .

A 22 de novembro do mesmo ano assume o cargo em sessão solene da Congregação, a qual, além do corpo docente e discente, compareceram representantes do Conselho Universitário da USP, da Ordem dos Advogados de São Paulo, do Sindicato dos Jornalistas, do Centro Acadêmico XI de Agosto e outras altas personalidades do círculo jurídico.

Preside à mesa o Reitor da Universidade, professor Miguel Reale, que, abrindo a sessão, designa o professor emérito Ataliba Nogueira, e os professores Goffredo Telles Júnior 
e Nicolau Nazo para introduzirem o novo titular do DIP na doutoral, onde é recebido entusiasticamente.

Logo após a cerimônia de investidura, foi dada a palavra ao professor Goffredo Telles Júnior que, em nome da Congregação, saúda o novo mestre, referindo-se ao caráter eminentemente universitário de suas intensas e múltiplas atividades.

\section{Saudação do Professor Goffredo Telles Junior.}

O orador principiou sua saudação com as seguintes palavras:

"Esta é a hora e vez de Irineu Strenger.

Da tribuna em que me encontro, mesmo de longe, creio que adivinho, na vivacidade de seus olhos espertos, a emoção que o domina, ao viver o mais glorioso momento de sua existência.

Não, não foi fácil, para Irineu Strenger, chegar até aqui. Os que o conhecem, colegas e observadores, sabem de sua árdua campanha. Sabem de como teve que lutar e de como efetivamente lutou, com inexcedível bravura e rara competência, para vencer ciladas e traições. E sabem de como travou o bom combate, galgando, de um em um, sem desfalecimentos e sem favores, os íngremes degraus da carreira universitária".

Depois, o orador traçou a biografia do homenageado. Realçou os fatos principais de sua vida, dizendo, em resumo, o seguinte:

"Irineu Strenger, licenciado pela Faculdade de Filosofia, Ciências e Letras da Universidade de São Paulo, matriculou-se, em 1953, na Faculdade de Direito do Largo de São Francisco. Bacharelou-se em 1957.

*. O discurso foi fixado pelo serviço de gravação da Faculdade de Direito. 
Quando ainda aluno da Academia, teve participação ativa em dois Congressos Internacionais de Filosofia: no de São Paulo, em 1954, e no de Washington, em 1957.

Os resultados de sua aplicação aos estudos não se fizeram esperar. Miguel Reale o convocou. E, durante oito anos, de 1957 a 1964, Irineu Strenger foi professor do Instituto Brasileiro de Filosofia.

Nesse período de ensino livre, a versatilidade e o universalismo de seu espírito se patentearam na variegada gama de disciplinas que ministrou. Seus cursos versaram: Filosofia da Política, em 1957; Positivismo e Evolucionismo no Século 19, em 1958; O Pensamento Político da Antiguidade aos Nossos Dias, em 1959; O Pensamento Político Moderno e Contemporâneo, em 1960; Diretrizes da Ciência Política e da Filosofia do Estado no Brasil, em 1961; Panorama da Psicologia Contemporânea, em 1962; Psicologia Infantil, em 1963; e Psicologia da Delinquência Juvenil, em 1964 .

Na Revista Brasileira de Filosofia, o Prof. Strenger vinha publicando seus primeiros trabalhos. Em 1957, publicou Marxismo e Positivismo; em 1958, A Matéria como Categoria Filosófica; em 1959, Influências de Husserl no pensamento jusfilosófico brasileiro e O Problema da Liberdade na Órbita do Direito; em 1960, A Noção Espaço Tempo na Filosofia Pós-Hegeliana; em 1961, Da Liberdade segundo Spinoza e Dimensão Filosófica da Liberdade.

Publicou, também, em edições particulares, Filosofia do Maquinismo, em 1959, e Originalidade do "cógito" de Descartes", em 1960.

Em princípios do ano letivo de 1962, Miguel Reale apresentou Irineu Strenger a seus alunos da Faculdade de Direito. Disse de quem se tratava e que o Prof. Irineu havia sido escolhido para Instrutor Voluntario de Filosofia do Direito e para condutor do seminário dessa disciplina." 
Sobre o inicio da carreira docente do Prof. Irineu Strenger na Universidade de São Paulo, as palavras do orador foram textualmente as seguintes:

"Vêde, meus eminentes amigos, que Irineu iniciaria sua caminhada pelo primeiro, pelo primeiríssimo degrau da carreira universitária, ou seja, como Instrutor Voluntário.

Ele próprio me narrou o que foi sua estréia. Naquele tempo, anos antes da Reforma, quase ninguém sabia, em Faculdades do tipo tradicional, na área das ciências humanas, o que era propriamente um seminario. Na Faculdade de Direito, os fracassos sucessivos das chamadas "aulas práticas" bem provam o que acabo de dizer. Na verdade, não se dava às sessões de seminario a menor importância. A freqüência a tais sessões era facultativa. E os professores dos cursos, em regra, se esquivavam dos ônus dos seminarios, descarregando-os sobre os ombros dos assistentes e dos instrutores.

No dia de sua iniciação, Irineu Strenger encontrou, dentro da grande sala vazia, oito rapazes de boa vontade. Oito, dos cem de que se compunha a turma completa. Mas ali estavam aqueles oito.

Transbordando de uma felicidade edênica, a vibrar de uma emoção virginal, pondo sua alma no que fazia, Irineu principiou, diante dos oitos curiosos, seu apostolado de professor universitario.

Irineu Strenger foi Instrutor Voluntario durante três anos. O orador lembrou a constante presença do novo professor em sua escola, durante esse primeiro período. Irineu dava a impressão de viver na Faculdade. Dedicou-se a ela com fervor. Era visto de manhã, às tardes, muitas vezes à noite, nas dependências da Academia. A partir dessa época, Irineu passou a fazer parte da paisagem de nossa escola. É verdade que não o encontrávamos, com frequencia, na Sala dos Professores. Tenho a impressão de 
que uma natural timidez o inibia, deixando-o arredio, impedindo-o de entrar, ainda na qualidade de Instrutor, na solene Sala das Becas. Mas, nos corredores, no páteo, sobretudo na sala do Secretário, ali estava ele sempre. A Faculdade passou a ser a sua segunda casa, seu ambiente familiar, e todos nós sabemos o que isto significa para um verdadeiro professor".

Assinalou o orador que os cursos ministrados por Irineu Strenger, nessa época, a dedicação por ele demonstrada, não lhe proporcionaram nenhuma remuneração. Como voluntário, não tinha direito a vencimentos. " $E$ nós, os velhos, que o observávamos em segredo, pudemos notar que ele tudo dava de si, sem nunca reclamar ou pedir qualquer compensação.

Os recursos necessarios para a sua vida, Irineu os tirava de sua advocacia. Mas, seu próprio escritório, ele o montou alí mesmo, encostado ao Largo de São Francisco, nas imediações da Faculdade, como a significar que seu escritório era, para ele, uma simples continuação de sua escola.

Disse o orador: "Irineu me revelava, ainda há poucos dias, que a Faculdade de Direito é o seu natural refúgio. Aqui é que ele vem encontrar o "relax" de que precisa. Aqui é que acha o refrigério de que necessita, em contato com seus colegas, em comunhão com seus amigos.

De 1952, datam dois trabalhos seus, na Revista Brasileira de Filosofia: Rousseau e a Escola Positivista e Controvérsias em torno do pensamento rousseauniano.

Em 1963, participou do Congresso Internacional de Filosofia, no México, tendo apresentado a tese Problemática Humana da Técnica.

Em outubro de 1964, Irineu se submeteu a concurso, para a conquista da Livre Docência de Filosofia do Direito. $O$ orador fez parte da comissão examinadora. $O$ candidato demonstrou competência e qualidades de professor. Foi aprovado. 
Desde então, Irineu Strenger começou a abrir caminho. Começou a avançar em sua carreira de Professor Universitário.

Aos 2 de abril de 1965, é nomeado Professor Assistente de Filosofia do Direito. No mesmo ano, na ausência do Prof. Gama e Silva, é designado para reger a cadeira de Direito Internacional Privado.

Esta última designação constituiu um fato inesperado em sua vida. Inesperado, mas decisivo. Lembrou o orador que Ortega e Gasset dissera que "eu sou eu e a minha circunstância". A designação inesperada para reger cadeira que não era a sua, foi a "circunstância" que haveria de decidir da carreira de Irineu Strenger.

Cumulativamente, ele dirigia o seminário de Filosofia do Direito e ministrava o curso de Direito Internacional Privado. Muito ocupado com essas duas incumbências, Irineu Strenger vivia em razão da Faculdade.

Em 1966, publicou, na Revista Brasileira de Filosofia, um importante trabalho: Fenomenologia $e$ Criticismo Ontognoseológico, no qual expôs as inovações de Miguel Reale, trazidas ao movimento husserliano mundial.

Em setembro de 1966, o Prof. IrIneu causou surpresa para toda a Faculdade: inscreveu-se no concurso de livre docência de Direito Internacional Privado. Por força de sua "circunstância", o filósofo enveredava por uma disciplina especializada da árvore jurídica.

Antes da realização das provas, em princípios de 1967, o Prof. Irineu é contratado para reger, no Curso de Especialização da Faculdade de Direito, a cadeira de Direito Internacional Privado. Como é sabido, esse curso era destinado a bacharéis em Direito e regido, em regra, por catedráticos.

O concurso se realizou em outubro de 1967. A tese do Prof. Irineu se intitulava Da Autonomia da Vontade em Direito Internacional Privado. O orador foi um dos com- 
ponentes da Comissão Examinadora. As provas revelaram o mestre. E o candidato foi aprovado com distinção.

Depois de ter sido bacharel duas vezes, Irineu Strenger é, agora, duas vezes livre docente.

A partir dessa época, teve oportunidade de manifestar seus dotes de professor, em cursos múltiplos. Regendo a disciplina de Direito Internacional Privado, nos referidos Cursos de Especialização, versou, durante os anos de 1968 a 1970, as seguintes matérias: $O$ trabalho interpretativo do juiz em Direito Internacional Privado; A filosofia jurídica de Francisco de Vitória; Direito Internacional Privado nos países socialistas; A lei pessoal: sua interpretação no Direito Internacional Privado; A apatrídia no Direito Internacional Privado; Homologação da sentença estrangeira em matéria civil no Direito estrangeiro.

Em 1968, deu um curso de Direito Espacial, que foi o primeiro, sobre esse assunto, em nossa Faculdade.

Em 1971, Irineu Strenger se viu encarregado do Curso de Pós-Graduação - de Mestrado e de Doutorado - da disciplina de Direito Internacional Privado Marítimo.

Nos anos de 1968 a 1971, teve participação ativa em quatro congressos internacionais de Direito: no de Viena, em 1968; no de Pescara (Itália), em 1969; no de Haia, em 1970; e no da Bélgica em 1971.

No corrente ano de 1972, está expondo, em seu Curso de Pós-Graduação, matéria subordinada ao título Proteção do Investimento Privado Estrangeiro, nos países subdesenvolvidos".

Neste ponto de seu discurso, o orador acentuou o caráter eminentemente universitário da atividade de Irineu Strenger. "Nada mais é preciso dizer para que se verifique que Irineu Strenger é, de fato, uma revelação de Professor Universitário. É com intenção que eu digo "Professor Universitário", e não "Professor de Direito". Vejam, meus senhores, que ele não é, apenas, o Professor de uma disci- 
plina de Direito. Ele é um mestre das ciências humanas e é um filósofo. Ele é um mestre de Direito, mas um mestre que conhece a posição do Direito, dentro do Universo. Ele é um Professor de Direito, mas é, antes de tudo, um Professor da Universidade. Seu espírito é um espírito de universalidade. $\mathrm{t}$ um espírito de Universidade. Tudo, sim, na Faculdade de Direito, o interessa; mas tudo, também, tudo, na Universidade, o interessa igualmente. Irineu é um apaixonado por sua Escola, mas é um apaixonado, também, por sua Universidade.

Este, certamente, é o motivo, diz o orador, pelo qual Irineu Strenger vem exercendo diversas funções administrativas, na Universidade de Miguel Reale. Ele foi Diretor do Instituto de Saúde e Serviço Social e Coordenador da Coordenadoria de Saúde e Assistência Social. É Membro Titular da Comissão da Editora da Universidade. É Membro Titular do Conselho Estadual de Saúde, como representante da Universidade, para a área de Ciências Humanas. No Conselho Universitário, é membro suplente.

$O$ orador chamou a atenção para o fato de que a atividade de Irineu Strenger não se limitou ao exercicio de suas funções universitárias. Fora da Universidade, também, intenso vem sendo seu trabalho. Ele foi Diretor da Faculdade de Comunicações da Fundação Armando Álvares Penteado. Foi membro do Conselho Estadual de Cultura e Presidente da Comissão de Ciências Humanas. Atualmente. é membro da Comissão Internacional de Juristas, Secção de São Paulo; da "International Law Association" e da Sociedade Brasileira de Direito Internacional.

Esse, o Professor que foi aprovado, com distinção, no último concurso para Professor Titular do Departamento de Direito Internacional da Universidade de São Paulo"

O orador finalizou seu discurso de saudação dizendo que a carreira de Irineu Strenger era motivo de fecunda meditação sobre o papel do professor universitário. Afirmou que a proclamada reforma do ensino do Direito 
não podia se limitar a uma reforma de currículo. "Uma verdadeira reforma é uma reforma dos processos de ensino. Mas a implantação dos modernos processos de ensino exige uma completa reforma da mentalidade docente. Disse o orador que o Direito precisava ser estudado em laboratório, em regime de dedicação integral. Dedicação integral, sim, por parte do corpo áocente e do corpo discente. $\mathrm{E}$ os professores e alunos de Direito precisavam se compenetrar de que o Direito é vida e não apenas forum; é muito mais vida extraforum do que vida no forum. Este é o motivo pelo qual uma simples mudança de currículo, com a inclusão ae arsciplinas como a "prática forense" e "organização judiciária", não constitui nenhum progresso verdadeiramente significativo. Os grandes problemas do Direito moderno e do profissional moderno do Direito nada têm com essas disciplinas. A advocacia de hoje se faz, em sua maior parte, longe do forum, longe da prática forense e da organização judiciária.

Como se distingue uma incorporação e uma fusão de empresas? Em que consiste essa curiosa promessa de casamento de empresas, ou esse casamento de experiência, que antecipa a fusão e que se chama consórcio de empresas? Qual a disciplina das sociedades de capital aberto? Que normas regem a "trading company"? De que parcelas se compõe o capital de giro? Que é uma reserva para depreciação ou uma provisão para devedores duvidosos? A que se reduz o fundo de correção monetária? Quais são os processos de incorporação do fundo de comércio? Em que consiste esse artifício engenhoso, inventado por banqueiros, condenado pela lei, que se chama uma "operação casada"? Como distinguir uma autarquia de uma empresa pública, e ambas de uma sociedade de economia mixta? Qual a exata situação jurídica dos elementos componentes de tais entidades?

Estas e centenas de outras questões análogas, relacionadas todas com a grande luta da vida dos tempos atuais, 
é que deveriam constituir o objeto central dos estudos jurídicos.

O moderno estudo do Direito precisa ser feito em seminários, com pequenas turmas de alunos participantes, sob a orientação de técnicos abalizados. $O$ que é necessário é incutir no estudante, colocado diante dos fatos concretos, o hábito de pensar juridicamente.

Docentes atualizados, como Irineu Strenger, bem sabem que estão condenadas as turmas oceânicas de alunos, os professores diletantes, os imensos cursos de conferências teóricas.

Necessárias, sem dúvida, as aulas teóricas. Mas devem ser poucas, apenas para a exposição sintética das grandes instituições do Direito; apenas para a descrição dos grandes quadros jurídicos, dentro dos quais os próprios alunos, dirigidos por seus orientadores, irão descobrir as disposições reguladoras dos casos concretos.

Para a missão universitária dos tempos atuais, cada vez mais se faz sentir, na Faculdade de Direito, a exigência de amplos quadros de professores em regime de grande dedicação à docência e à pesquisa. Não de professores de improviso, mas de professores de carreira, formados em nosso Curso de Pós-Graduação, professores que se apurem nas árduas campanhas do Mestrado, do Doutorado, da Livre-Docência, professores instruídos na arte do magistério, experimentados, treinados, aperfeiçoados, e, afinal, formados para ensinar, dirigir e orientar a mocidade da Escola.

Irineu Strenger sabe -- disse o orador - que a hora presente é, por excelência, a hora do jurista. Técnica da disciplina social, o jurista é quem tem nas mãos a chave $d a$ convivência. $\mathrm{E}$ essa é, precisamente, a chave mais requestada, no momento atual. Na imensa confusão dos tempos modernos, não há quem não precise dela. A ciência do jurista se faz necessária, em todos os setores da vida: para a solução dos problemas familiares, para a orientação pro- 
fissional, para a administração das empresas, para a estruturação da ordem política, para a direção dos Poderes Públicos. Qualquer atividade, no emaranhado das relações sociais, logo exige a orientação e a assessoria do jurista.

Demonstrou o orador que a própria segurança nacional depende do jurista. Porque, ou ela se estrutura juridicamente, ou se transforma em "camisa de força". E se ela for "camisa de força", será, em vez de segurança, insegurança e vilipêndio.

O grau de aprimoramento de uma sociedade se mede pelo grau de respeito dos Poderes Públicos aos direitos da pessoa humana. Quando a segurança das pessoas é ameaçada por qualquer outra segurança, quando ninguém tem segurança porque a "espada" põe em risco o equilíbrio da "balança", a história registra um retrocesso penoso, na marcha evolutiva da civilização. Mesmo nos momentos amargos dessas tristes recuadas, o que mais se exige é a atuação perseverante, às vezes heróica, do jurista.

Triste espetáculo de primarismo mental, dão os denegridores da justiça e do jurista!

"Deixemo-los falar!" Exclama o orador. "Não sabem o que dizem. E eles mesmos, a cada passo, precisarão do jurista. E quando a sua pesada onda se perder, ainda mais precisarão do jurista, para não serem lapidados".

O Prof. Goffredo Telles Junior terminou sua oração com as seguintes palavras:

“Ensinar o Direito é educar. Educar não é apenas instruir. É instruir e formar. A Ciência do Direito é o requinte da ciência do relacionamento humano. Em última análise, Direito é Política.

A Velha Academia desabrocha numa Escola Técnica de Direito. E este é o sentido político de nossa Faculdade. Professores como Irineu Strenger estão convictos de que formar grandes técnicos do Direito é decidir do destino nacional". 


\section{Discurso de agradecimento de Irineu Strenger.}

Após a saudação do professor Goffredo Telles Júnior, Irineu Strenger profere seu discurso de posse, nos termos seguintes :

- "Tenho a consciência de que devo pronunciar um discurso, ou dizer palavras que preencham na formalidade temporal de um ato solene, tudo aquilo que pudesse traduzir de maneira fiel e comunicativa o que sinto num momento como este. Mas, a eloqüência é o privilegio divino da palavra, a inspiração resplandecente, a convicção eletrizada, a verdade em erupção. Sob essa potência a estimularme os sentimentos, penso, porém, não poder vencer o esforço que me proponho de aproveitar o que se apodera da alma e abrir o espírito, aceitando os ditames da força invisível que ora de domina. Quero abraçar a todos, quero expandir-me em gritantes alegrias, quero chorar, quero sorrir, gargalhar, quero tudo, quero lembrar meus amigos, quero perdoar meus inimigos, quero entregar-me à volupia espiritual deste instante, "com as transparencias da onda, as surpresas do vento, os reflexos do ceu e o descortino do horizonte".

"As noções conturbadas que envolvem meu pensamento, vou alinha-las, no esforço sobrehumano de vencer as afetividades e contrapor ao subjetivo o objetivo. $O$ primeiro ef eito desse esforço coloca-me em retrospecção. Recuo e avanpo na infinitude e descontinuidade do tempo e procuro realizar a experiência intersubjetiva do amor.

"Essa meditação ocasional e fragmentária é o tipo de aproximação que o tempo requer, e o estilo filosófico que se revela: a necessidade de uma perspectiva múltipla $\mathrm{c}$ obliqüa para aprender a realidade em movimento e suas ambigüidades. Prefiro superar minhas vacilações e vencer as hesitantes fórmulas expressionais, associando numa esquemática singela as categorias filosóficas que se associam 
no meu raciocínio sofredor e ao murmurá-las no borborinho desordenado da auto-análise, projetar a meu ver na sua amplitude máxima ou mínima, sucumbido diante da emoção que me arraza.

"O campo de presença que se forma neste relacionamento do meu Eu e os Outros cria uma rede de intencionalidades, na qual cada momento gera um momento novo. Cumpro um ato de transcendência. Assumo, pois, o meu ser sofredor de ontem, como o que não sou hoje, como o que está a distância de meu ser atual, mas como presente de meu passado, submeto-me à dialética do tempo. Eis aí a primeira categoria do meu roteiro auto-analítico.

“As maneiras de invocar os dados autobiográficos sofrem as desarticulações engendradas pelas quantidades e qualidades do dinamismo interno e obedecem a realidade na medida em que esta foi integralmente assimilada ao pensamento. Todo homem é esta tensão entre a unidade do realizado e a dispersão do que elabora, entre a segurança de um sentido e a incerteza da criação. Mas, sem dúvida, necessita manter essa tensão para continuar sendo humano. Lembrar é manter a tensão como válvula do humano. $\mathrm{E}$ a primeira projeção de interioridade não me leva à infância ou a juventude com recordações especiais, mas reverencio-me na lembrança dos meus primeiros mestres e agradeço-lhes anonimamente o que fizeram por mim, as estimulações à minha curiosidade, as sementes que germinararn na minha formação e aquela dedicação carinhosa e amiga que não se apaga. A esses mestres, autores benignos do meu ser, que foram a árvore dadivosa, cujos benefícios sobrevivem no reconhecimento que não murcha, a minha eterna gratidão.

"E neste exórdio de saudade e gratidão conservo assimilada em minha memória a imagem da bondade e da pureza daquela que me trouxe ao mundo e hoje não pode rejubilar-se desta festa de comovente prestação de amizade. Mas de onde ela estiver, saberá de minhas reverências 
incessantes aos seus merecimentos incontáveis, e gratidão que proclamo carinhosamente. Ao meu pai, com seu largo sorriso de satisfação, compartilhando desta felicidade, pelo que fez, sentiu e sofreu por mim, as homenagens que merece.

"Se o testemunho da história não me trai, se a memória não tropeça nas dobras do esquecimento, precisamente nesta época há 30 anos atrás, com os meus dezenove anos incompletos, pela primeira vez senti o poder penetrante e dominador das Arcadas. Embora vindo a ser seu aluno muitos anos mais tarde, aqui aprendi como universitário de Faculdade de Filosofia, a cultuar e amar a liberdade. Conservo vivos os estribilhos entusiastas dos acadêmicos de então, irmanados na luta contra o totalitarismo e animados pela ânsia de liberdade tantas vezes abandonada pelas criaturas que a pregam. E lembro-me bem do dia auspicioso da vitória, todos aqui presentes, vivendo a emoção irresistível do triunfo, irmanados na idéia comum. Desfrutei assim, das Arcadas a sua tradição, o seu calor, o seu sistema. E desde aí, amei-a sempre.

"Quis o destino que o fascinio que me tomara, viesse a consolidar-se cada vez mais, num processo que nunca cessou, pois contaminou-me daquela sadia ansiedade de sentar-me ao lado de meus queridos mestres, para imitá-los no labor incessante, que justifica e consagra a tradição desta Casa. Eis-me aqui, no último degrau da carreira, recebendo as homenagens inesquecíveis daqueles que foram os responsáveis pelos meus sucessos, e daqueles que colaboraram na palmilhada áspera da ascensão magisterial e ajudando-me a aparelhar a ferramenta do trabalho. Na falta da riqueza vocabular, indispensável para surpreender todas as gradações e matizes do pensamento, só posso dizer que a cada um de meus colegas reservo uma palavra de afeto, que não precisa ser pronunciada.

"Mas, se pudesse usar uma proposição jurídica para expressar outra proposição sentimental, talvez não houvesse 
nada mais apropriado do que afirmar com Miguel Reale, para Miguel Reale, que não existem valores sem referibilidade e, por isso, não posso deixar de considerar de maneira toda especial a projeção do meu espírito na experiência vivencial que tive ao seu lado. Diria mesmo que os nexos de complementariedade, que se formaram entre nós, discriminam as esferas autônomas do meu agir. Assim é pensado Miguel Reale por mim, em termos de nós, com a perda da validade singular do ego e do alter, cuja coorde nação aquele termo significa.

“Considero-me feliz por ter realizado com Miguel Reale os valores da convivência, de maneira concreta, admirando-o pelo seu saber invulgar e, principalmente, pelo respeito que sempre devotou às amizades, sem prejuízo de suas convicções, que o espelham como um homem impar, uma personalidade superior e digna. Sabem o meu mestre Miguel Reale e sua digníssima esposa minha querida amiga da. Nice que a estima por ambos suplanta o teor das meras palavras, mas, que elas signifiquem neste momento o reflexo do meu sentir.

"Há palavras que liberam e há palavras que comprometem. Não me refiro ao poder catártico liberador da palavra, que já foi suficientemente tratado desde Aristóteles até nossos dias, mas, ao seu sentido aglutinante, coerente, como pão, amor e comunhão. A palavra quando brota carregada radioativamente de afetividade além de liberar-se constitui numa cadeia, num elo, porque forte é o seu dom mágico de aproximar ou desunir os homens.

“Toda palavra que emana das profundezas é cápsula de fogo capaz de incendiar a alma. A palavra fria, sem entusiasmo ou espontaneidade, não serve para as formas, mas, para as fórmulas. $\mathrm{E}$, precisamente nessa desbordagem, refletida de emoção, liberta de censura íntima, deixei borbulhar as idéias e comecei a pensar, sem a preocupação da riqueza expresional, procurando esforçadamente sair do sonho, comecei a pensar no que significo para as Arcadas e no que elas significam para mim. Como poderia transmi- 
tir a este Templo do Ensino Jurídico mais que centenar o meu afeto, o meu reconhecimento, a minha dedicação? Como prestar-lhe o meu juramento. E a palavra transformada em palavras era sempre a mesma: liberdade. Pode falar-se na Academia do Largo de São Francisco, sem pensar na liberdade? A que seria devido esse estranho fenômeno. Achei que a explicação estava nas paredes, nos murmúrios das vibrações que pairam permanentemente na atmosfera inteira dos salões, das salas de aula, na força irresistivel da Tradição, nos bustos, nos quadros, na figura penetrante de Rui Barbosa, na memória dos grandes mestres que por aqui passaram. Achei que a idéia de ordem, de justiça, de liberdade, de disciplina, compõem a estrutura das Arcadas, são as colunas que as sustentam. Pensei nas palavras de Reynaldo Porchat: "O direito é uma força. E esta academia é uma ancora secular. Nela se prendem as gerações que daqui partiram, sob este céu imenso do cruzeiro do sul, e foram esparzir luz sobre a extensão da Pátria querida.. Não houve grande causa nacional que não encontrasse aqui o apoio da inteligência, da palavra e da ação. Nos problemas sociais e políticos, sempre fornecemos o contingente máximo... Os bacharéis que daqui saem aprenderam a conhecer e a sentir a justiça e a liberdade." Saboreio espiritualmente as palavras candentes de Ruy: Liberdade "só por ti se discriminam autenticamente os regimes. Tua presença faz as repúblicas, dando-lhes o governo da opinião, fórmula necessária da realidade. Tua ausência as infama, as desmacara, as arruina, insurgindo contra elas as tuas forças, as maiores que a nossa natureza conhece, as que revolvem até o fundo da alma humana, as que levantam, ao grito da consciência, as pedras das calçadas, as que fazem pairar sobre as revoluções o espírito de Deus. Ai dos que poem as mãos em tua arca, ó liberdade que ergues as nações, e abates imperios. As democracias, que atentam contra a tua magestade, perecerão na tirania dos Césares, ou na anarquia das ruas." 
"O problema do valor leva-nos, portanto, diretamente aos domínios da cultura. E se há possibilidade de Valores, como afirma Miguel Reale, é porque, quem diz homem diz liberdade espiritual, possibilidade de escolha constitutiva de bens, poder de síntese com liberdade e autoconsciência.

"Ainda arrebatado pelas vibrações com que minha alma foi sacudida neste momento único da vida universitária, acresço às manifestações candentes e carinhosas do meu estimado mestre e amigo prof. Gofredo da Silva Teles Jr. que com o seu brilho inexcedível, sua palavra fácil e fluente, ao lado de aquinhoar-me, gentilmente, com frases que me enaltecem e sensibilizam, trouxe, como sempre no conteúdo de sua oração inflamante a lição proveitosa, versando com riqueza substancial alguns problemas fundamentais da vida desta Escola, fazendo-o com eloqüência pura e sincera, neste instante sublime de lenir as dores e sarar os desalentos, descobrindo-nos nos opulentos veios de ouro de sua cultura, por onde havíamos de aprender a conhecer a essência mesma do Direito. Ao insigne professor peço que perdoe, com a costumeira generosidade, a pobreza das expressões, em confronto com a intenção malograda de manifestar-lhe o quanto sou grato, por tudo que recebi, e continuo recebendo do nosso convivio, que espero seja cada vez mais consolidado e efetivo. Na realização da homenagem tão significativa e comovente, fostes o orador talhado para a solenidade, o jurista, que tão magistralmente preleciona na cátedra, sustentando o império do direito, membro ilustre dessa plêiade de ínclitos mestres, dentre os quais sois uma expressão viva e legítima de altíssimo quilate.

“Aos estudantes não poderia omitir o fervor de minha estima, declarando-lhes que como professor procurarei manter o alicerce material e moral que nos alcança nesta Casa, desde a Antigüidade, que hoje certamente nos contempla, na sua indissolúvel solidariedade, e na sua fraterna e inextinguível unidade, esta instituição criada ao equilíbrio da 
justiça, da liberdade e do direito, florescente de aspirações e intransigente com os seus ideais, pois, aqui nesta Casa nasceu a Independência da Pátria e "aqui cresceu e se tornou gigante, o nome querido de Mocidade Acadêmica".

"A vós Mocidade Acadêmica direi que, embora a adolescência em nossas sociedades seja uma etapa crítica, onde se sente com freqüência a iminência de perder o trabalhosamente alcançado sentido de identidade interna, e a força das dramáticas recomposições dos fragmentos, das graves exigências de uma cultura em rápida transformação, estou certo, nestas Arcadas acharemos as correlações necessárias para a realização dos destinos de nossa Pátria, pois, esta solidariedade que nunca nos faltou, decidirá no momento crucial do reencontro das mentalidades.

"Ao nosso diretor Prof. Pinto Antunes dirijo também minha especial homenagem, reconhecendo o seu labor em prol de nossa Faculdade, dando de si o sacrifício e a sua capacidade de participar com sabedoria, nas complexas vicissitudes administrativas.

"Para Drinadir Coelho o meu afetuoso abraço de amizade e os votos para que essa criatura de todos nós tão estimada sempre permaneça ao nosso lado, com o seu sorriso incomparável.

“Nossos filhos são freqüentemente os juízes cujas sentenças mais prezamos ou mais tememos, porque podem orgulhar-se ou ter vergonha de nós. A eles o fundo do meu pensamento e a certeza de que minha vida não teria valor, se os desiludisse.

"Reune esta oração alguns fragmentos de meu espírito inquíeto e independeñte. Não organizei temas. Lancei-me na aventura das frases soltas. Quis provocar minha intimidade. Deixá-la à vontade. Não martirizá-la. Sofro as conseqüências de alguns eventuais incidentes verbais, mas, não me arrependo dessa atitude, porque poderei dizer a todos que ouviram a voz da sinceridade. 
“Peço, todavia, licença, para neste final extravasar a minha maior e mais sentida homenagem, repleta de amor, admiração e reconhecimento e, sobretudo, a gratidão em sua maior amplitude, gratidão a Deus pela companheira que me deu, sempre companheira, sempre ao meu lado, nos bons e maus momentos, que não foram poucos. Sofrendo comigo, alegrando-se com as minhas alegrias. Ajudando-me sempre, em tudo, em qualquer condição, nas piores ou melhores circunstâncias. Vinte e sete anos juntos, estou certo, cumpriremos os sacramentos do matrimônio, na vida e na morte. A ela o registro das minhas linhas finais.

\section{Palavras do Reitor e encerramento da sessão.}

Terminado o discurso de agradecimento, o presidente da mesa encerra a sessão com palavras enaltecedoras do caráter de Irineu Strenger, em suas várias manifestações, e refere-se, também, aos novos departamentos como forma de entrelaçamento entre mestres e alunos, o que propiciará o vislumbre de vocações docentes, seu estímulo e formação pelos mestres.

A seguir, palavras do Reitor, professor Miguel Reale:

"Meus senhores, toda cerimônia de recepção solene de professor nesta Casa tem fisionomia especial. Esta noite, não desejo falar apenas como Professor da Faculdade de Direito, do que tanto me orgulho, mas também como Reitor da Universidade, a fim de por em realce outra faceta da personalidade que hoje estamos homenageando.

"Quero me referir a Irineu Strenger como homem, lembrando o que ele tem sabido demonstrar, ao longo de sua vida, no que se refere à dedicação e ao amor.

"Tenho a certeza de que soube construir com segurança porque tem sabido dar com desprendimento. Desde a primeira vez que o encontrei foi para impor-lhe um dever, para chamá-lo à primeira responsabilidade. Durante oito 
anos lecionou ele, sem qualquer remuneração, no Instituto Brasileiro de Filosofia, contribuindo, de maneira extraordinária, para a consolidação dessa entidade. Jamais fez qualquer reclamação, jamais postulou favores. De outra feita, também foi para cumprir um dever, o de lecionar nesta Casa, durante vários anos, como assistente voluntário.

"Nessas duas oportunidades jamais ouvi de Irineu Strenger qualquer pronunciamento que significasse estar se valendo de seu próprio trabalho, de sua dedicação, com intuito que não fosse apenas o de bem servir.

"Posso dizer que, neste momento, na Universidade de São Paulo, a imagem de Irineu Strenger é essa, na direção da coseas, Coordenadoria de Saúde e Assistência Social, que é a que abre os braços para nossa juventude, assegurando ao estudante condições existenciais condignas.

"A obra que Irineu Strenger está realizando na coSEAS, com a cooperação de dedicados mestres e funcionários, é uma obra que marcará, sem dúvida, a história da Universidade de São Paulo. Ainda agora, recebendo vários Ministros de Justiça de toda a América Latina, o que mais os empressiontu na usP, ao lado da magnitude tecnológica e científica, foi o Serviço de Saúde e de Assistência Social, considerado modelar, não apenas na América, mas em todo o mundo.

"Obra desse tipo só pode ser feita com dedicação e com amor, por homens habituados a dar, sem a preocupação de receber.

"Mas desejo por em realce outro aspecto da vida de Irineu Strenger, que é a sua capacidade de aliar a capacidade especulativa com as responsabilidades da vida prática. Sempre admirei e admiro os homens que não se trancam dentro do seu próprio pensamento mas, ao contrário, se servem do pensamento como um esboço de ação, entrelaçando, de maneira concreta, a idéia com as exigências da praxis social. Quando moço, mal saído desta Casa, publicava meu primeiro livro, no qual esculpi al- 
gumas palavras que espero possam ser o rumo de toda a minha vocação de professor: "Teorizar a vida e viver a teoria na unidade indissolúvel do pensamento e da ação".

"Sinto que Irineu Strenger se integra nessa concepção de vida, dedicada à idéia que se torna ação e retorna para expressar-se totalmente em novas idéias. Este é o dever máximo, sem dúvida alguma de um professor. Porquanto nós, mestres, ao lado de tantos problemas, responsabilidades e preocupações, gozamos de um privilégio, o de roubarmos um pouco da eternidade através daquilo que nos é dado transmitir através de nossos discípulos.

"Toda vez que encontro um discípulo, sobretudo, quando assume, como neste caso, a responsabilidade de dirigir uma disciplina, toda vez que encontro um discípulo em postos da mais alta projeção, sinto-me altamente realizado, pois de certa forma, me projeto no tempo através de sua personalidade.

"Talvez se possa dizer que a vida humana é uma ilha de problemas cercada por um oceano de mistérios, a começar pelo mistério de nascer e o mistério de morrer. Mas há mais. Há mistérios que incidem sobre nossa pequena ilha existencial, como, por exemplo, o mistério de um encontro revelador que decide de nosso destino. $O$ encontro daquela que vai ser nossa companheira e nossa esposa; daquele que vai ser o nosso amigo; daquele que vai ser o nosso mestre; daquele que vai ser o nosso discípulo. Meus amigos, eu iniciei a atividade docente nesta Casa, numa época em que eram raros os encontros entre os professores e os alunos e bem difícil a um professor vislumbrar entre os seus discípulos aquele que tinha capacidade de receber o facho do magistério. Foi, por exemplo, lendo uma prova escrita, que descobri Renato Cirell Czerna e, num encontro com Luís Washington Vita, fiquei conhecendo Irineu Strenger... 
"O que desejo que não aconteça mais são apenas encontros eventuais desta natureza, substituídos, como devem ser, por encontros entre mestres e discipulos, no calor dos laboratórios científicos. Encontros na descoberta do mistério da palavra e do ensinamento, nos seminários de Direito. Só assim estaremos construindo uma cultura sólida, uma cultura que não esteja mais voltada para fora, mas se vincule às forças imanentes ao seu próprio destino. Um grande problema brasileiro é o da alienação de sua cultura. É preciso superarmos a alienação em que, até certo ponto, ainda vivemos. É tempo de vencermos a tendência, ainda dominante nos meios culturais brasileiros, de só pensarmos em receber de fora aquilo que deve ser antes espontâneo desenvolvimento das riquezas intimas de nosso espírito. No dia que tivermos esta consciência, os departamentos deixarão de ser repartições frias, para se transformarem num lugar de encontro dos auxiliares de ensino e dos doutores como o estudante que está olhando para o futuro com olhos que, não raro, enxergam mais do que os nossos. Nesse dia, o tempo terá outro significado, outra cor. Porque eu não me canso de dizer: o tempo nada é em si: é vazio, é adiáfaro. incolor. $O$ tempo tem a cor das nossas intenções, o calor de nossa amizade, o ritmo da nossa intencionalidade, do nosso esforço criador e de nossa vontade. Que encontros como este se repitam sempre, com sentido de participação, é o voto que faço nesta Casa Matriz do Direito Nacional.

Está encerrada a Sessão. 